Paradoxically, it is the very incompleteness that induces the reader to inquire further, which is the subject of "Czytanie" [Reading] (pp. 17-58), the first essay of the "Criminal Odyssey....". It serves as an "introduction to reading", complemented with the following essays which focus on specific problems and which, if examined separately, seem to be subject to the case studies of literary phenomena, poetics of specific writers, or motives.

One could also examine Burszta and Czubaj's work from another perspective and read it not as an anthropological interpretation of literature, but as a literary conceptualisation of anthropology.

\author{
Justyna Rudnicka \\ ORCID: 0000-0001-7635-2449 \\ Uniwersytet Wrocławski
}

\title{
Muzyka popularna słuchana i czytana
}

https://doi.org/10.19195/0867-7441.25.34

Recenzja: Grzegorz Piotrowski, Muzyka popularna. Nastuchy i namysty, Państwowy Instytut Wydawniczy, Warszawa 2016, ss. 170.

Słowa kluczowe: muzyka popularna, muzykologia, antropologia, popular music studies

Keywords: popular music, musicology, anthropology, popular music studies

Muzyka popularna jako przedmiot badań wciąż jest w polskim piśmiennictwie naukowym obszarem nowym i niezagospodarowanym ${ }^{1}$. Pytanie, jak należy ją badać, stawiane jest przez badaczy różnych dziedzin — socjologów, kulturoznawców, antropologów, wreszcie muzykologów - a odpowiedziom towarzyszą coraz liczniejsze próby naukowej analizy zjawiska dokonywane z rozmaitych perspektyw ${ }^{2}$. Jedną z takich prób jest publikacja Muzyka popularna. Nastuchy i namysty Grzegorza Piotrowskiego, która w 2016 roku ukazała się nakładem Państwowego Instytutu Wydawniczego w serii „Biblioteka Myśli Współczesnej”.

Niewielkiego formatu książka podzielona jest na siedem rozdziałów, z których każdy rozpatruje fenomen muzyki popularnej w innym kontekście. Autor rozpoczyna od kwestii oczywistych dla badaczy kultury popularnej, czyli od wskaza-

${ }^{1}$ Do ważniejszych polskich publikacji, które ukazały się w ciągu ostatnich kilku lat, należą chociażby Rewolucja rocka. Semiotyczne wymiary elektrycznej ekstazy (2011) Marcina Rychlewskiego czy Muzyka popularna jako wehikut ideologiczny (2011) oraz Muzyka popularna i jej odbiorcy w poszukiwaniu autorytetu (2017) autorstwa Marka Jezińskiego.

${ }^{2}$ Na temat współczesnych nurtów w badaniu muzyki popularnej zob. P. Gałuszka, Nowe nurty badawcze w studiach nad muzyka popularna — przeglad wybranych koncepcji, „Przegląd Socjologiczny" 2015, nr 3, s. 113-129. 
nia na istniejącą w tradycyjnej muzykologii zachodniej nadrzędną narrację, która traktuje obszary wyłączone z tak zwanego dyskursu artystycznego (czyli między innymi muzykę popularną) jako peryferyjne, mniej znaczące, a więc niewymagające dogłębnych studiów i klasyfikacji. Owej metanarracji przeciwstawia postmodernistyczną dezintegrację i przynależną jej niechęć wobec wszelkich odgórnych hierarchii, ujawniając jednocześnie własną sympatię dla tej drugiej perspektywy. Passus ten to również rodzaj metodologicznego wstępu, w którym autor przedstawia swoje założenie połączenia perspektywy antropologicznej z muzykologiczną.

Kilkustronicowy rozdział drugi traktuje o terminologicznej niejednoznaczności w obszarze badanego przedmiotu, po nim zaś następuje część, w której analizie zostaje poddana kategoria popularności. Badacz, wedle wcześniejszych zapowiedzi, analizuje muzykę popularną z dwóch perspektyw, stosując podział na ,zewnętrzne” oraz „wewnętrzne” aspekty popularności. Wśród pierwszych wymienia powszechną sprzedaż płyt, masowego odbiorcę i rolę mediów, czyli wszystko to, co składa się na tak zwany przemysł muzyczny. Czynniki te nie jawią się jednak autorowi jedynie w sensie negatywnym. Piotrowski nie zgadza się ze zdaniem, że muzyka (lub szerzej — kultura) popularna/masowa jest „,wyłącznie i bezpośrednio artykułem masowego spożycia, jak guma do żucia"3 czy przedmiotem zmuszającym ludzi do udziału w ,procesie masochistycznego przystosowywania się do autorytarnego kolektywizmu"4. Jako kontrargumenty przytacza fragmenty tekstów innych badaczy, którzy zwracają uwagę chociażby na rolę odbiorcy w procesie kreowania rynku muzycznego. Wreszcie, zdaje się mówić, nie można redukować muzyki popularnej do tego, co wobec niej zewnętrzne, i proponuje przyjrzeć się jej formie, strukturze, jakościom brzmieniowym.

W podrozdziale Aspekty wewnętrzne (s. 42-66) oprócz przywołania (oraz krytyki) ogólnych teorii dotyczących powstania muzyki popularnej oraz prób ujęcia jej specyfiki pojawia się również szczegółowe omówienie pojedynczego utworu - Just the Way You Are Billy'ego Joela (s. 59-66). Posługując się narzędziami typowymi dla muzykologii, autor poddaje analizie warstwę tekstową i muzyczną piosenki, by we wnioskach ustalić jej strukturalną prostotę, niepobawioną jednocześnie wewnętrznego wyrafinowania. Przykład zostaje uznany za idealnego reprezentanta muzycznego „tekstu wytwarzalnego” — kategorii stworzonej przez Johna Feiske'a, a zaadaptowanej przez Piotrowskiego na grunt muzyki.

Opis ,muzycznego kodu” (s. 67-104) realizowany jest na postawie podziału na pięć składników: „Wielkie style”, „Ekspresja wokalna”, „Improwizacja” oraz „Sound, harmonia, swing". Wśród podstawowych stylów muzyki popularnej autor wyróżnia pop, rock i jazz, jednocześnie informując czytelnika o umowności tej klasyfi-

3 Zob. D. Macdonald, Teoria kultury masowej, przeł. C. Miłosz, [w:] Antropologia kultury. Zagadnienia i wybór tekstów, red. A. Mencwel, Warszawa 2000, s. 479.

4 Zob. Th.W. Adorno, G. Simpson, On popular music, [w:] On Record: Rock, Pop, and The Written Word, red. S. Frith, A. Goodwin, New York 1941, s. 312, cyt. za: G. Piotrowski, Muzyka popularna. Nastuchy i namysty, Warszawa 2016, s. 34. 
kacji. W jej ramach kreśli jednak charakterystykę każdego stylu, wydobywając jego najważniejsze atrybuty. Nie czyni tego wyłącznie na podstawie specjalistycznych artykułów, odwołuje się również do wypowiedzi samych artystów czy spostrzeżeń poczynionych na podstawie własnej praktyki wykonawczej. Po charakterystyce skupionej na jakościach brzmieniowych pojawia się temat elementu wizualnego w wykonawstwie muzyki popularnej oraz jej aspektów performatywnych.

Rozważania Piotrowski zamyka przedstawieniem najważniejszych tendencji w popular music studies (rozdział wyjątkowo cenny dla polskiego czytelnika), by na ostatnich kartach przewrotnie zapytać: „czy muzyka popularna w ogóle istnieje?”. Pytanie to można potraktować zarówno jako figurę retoryczną, jak i krótką adnotację na temat $\mathrm{w}$ książce jedynie zasygnalizowany — mianowicie kwestię coraz mocniejszego zacierania się granic pomiędzy poszczególnymi nurtami.

Jedną z zalet omawianej publikacji jest bogata bibliografia. Piotrowski nie ogranicza się do cytowania i omawiania jedynie tekstów kulturoznawczych. Korzysta zarówno z pozycji muzykologicznych, jak i tych, które przynależą do językoznawstwa, nauk teatrologicznych czy filmoznawczych. Dzięki temu z powodzeniem udaje mu się zrealizować przyjęte zamierzenie, jakim jest połączenie dwóch perspektyw - zewnętrznej (muzyka w kulturze) i wewnętrznej (jej specyfika).

Z pewnością właśnie owa integracja różnych podejść badawczych (nienależąca do najprostszych, ze względu na specyficzne narzędzia i terminologię każdej dyscypliny) stanowi o wyjątkowości tej pozycji. Dopełnieniem teorii są liczne exempla - konkretne utwory i wykonawcy, w których przywoływaniu i omawianiu autor wykazuje wyjątkową biegłość. Dzięki owym przykładom pozycja ta może się stać tytułowymi „nasłuchami” również dla czytelnika. Na odbiorcy tekstu spoczywa jednak wymagające zadanie kluczenia między wieloma przypisami za specyficznym tokiem narracji autora, który wprowadza czytelnika w sam proces swoich poszukiwań, nierzadko pozostawiając kwestię nierozstrzygniętą. Pewnym utrudnieniem mogą być też liczne cytaty, które nierzadko zaburzają płynność wywodu. Można odnieść wrażenie, że autor wchodzi w rolę przewodnika, który wytycza wprawdzie własną trasę, ale wyłącznie pomiędzy tym, co w różnych dyscyplinach zostało na temat muzyki popularnej (i nie tylko) napisane. Bywa, że w nagromadzeniu cytatów głos samego Piotrowskiego nieco się gubi, ukryty za tezami różnorakich autorytetów.

Ujawnia się jednak we fragmentach dotyczących wykonawstwa (autor jest nie tylko pracownikiem naukowym, lecz także wokalistą) oraz artystycznej wartości muzyki popularnej. Szczególnie ta druga kwestia jest interesująca. Skoro bowiem Piotrowski czuje się w obowiązku bronić estetycznych walorów muzyki popularnej, oznaczać to może, że obszar ten w polskiej refleksji naukowej (przede wszystkim muzykologicznej) wciąż jeszcze musi walczyć o prawo do bycia badanym z równą uwagą, z jaką analizuje się tak zwane arcydzieła. I chociaż taki postulat w książce Piotrowskiego nie pada, można odnieść wrażenie, że autor 
byłby kontent, gdyby studenci muzykologii oprócz sonat Beethovena analizowali na przykład słynne Hello Adele, od którego analizy książka się rozpoczyna.

Mimo deklarowanej przez Piotrowskiego niechęci do wszelkich klasyfikacji i podziałów można w Muzyce popularnej odnaleźć nie do końca usprawiedliwioną schematyczność w stawianiu poszczególnych tez. Otóż, ujmując pewne właściwości popular music, autor bardzo często posiłkuje się porównywaniem jej do muzyki klasycznej, plasując oba nurty na dwóch biegunach. Owa opozycja jest szczególnie widoczna we fragmencie dotyczącym wykonawstwa. Określenie wykonawców muzyki klasycznej „maszynami do grania” w opozycji do twórczych, pełnych ekspresji muzyków z nurtu muzyki popularnej może zostać odebrane jako duże uproszczenie. I choć potwierdzeniem tego zdania mają być słowa Igora Strawińskiego, to należy pamiętać, że były one postulatem kompozytora, nie zaś konstatacją rzeczywistości ${ }^{5}$. Oczekiwania krytyków oraz doświadczenia melomanów uczestniczących chociażby w przesłuchaniach Konkursu Chopinowskiego zdają się wskazywać na coś całkowicie innego, zarówno jeśli chodzi o rolę ekspresji i kreatywności wykonawcy, jak i jego cielesność — nie zawsze skonwencjonlizowaną czy przeestetyzowaną, przepełnioną „wypadkami ciała”. Należy jednak przyznać, że ta nieco przesadna polaryzacja spełnia swoją funkcję — służy wyraźniejszemu ukazaniu specyfiki omawianego przedmiotu, jest również jednym z wyrazów osobistego zaangażowania autora w omawianą tematykę.

Muzyka popularna. Nastuchy i namysty nie jest podręcznikiem akademickim, zresztą, co zostaje podkreślone we wstępie, wcale nim być nie chce. Już sama forma plasująca się pomiędzy rozprawą naukową a esejem, który czasami przybiera charakter apologii, sprawia, że książkę należy czytać raczej jako rodzaj wstępu do podobnie nakierowanych badań. Poruszając wiele wątków oraz budując bogate zaplecze historyczne i metodologiczne, Piotrowski kreśli jedynie szkic różnorodnych dróg, niejako zachęcając potencjalnych badaczy do głębszego spenetrowania którejś z nich.

\section{Bibliografia}

\section{Teksty}

Piotrowski G., Muzyka popularna. Nasłuchy i namysły, Państwowy Instytut Wydawniczy, Warszawa 2016.

\section{Opracowania}

Adorno Th.W., Simpson G., On popular music, [w:] On Record: Rock, Pop, and The Written Word, red. S. Frith, A. Goodwin, Routledge, London-New York 1990, s. 256-267.

5 Zob. I. Strawiński, O wykonaniu, [w:] idem, Poetyka muzyczna, przeł. S. Jarociński, Kraków 1980, s. 67-78. 
Gałuszka P., Nowe nurty badawcze w studiach nad muzyka popularna - przeglad wybranych koncepcji „Przegląd Socjologiczny” 2015, nr 3, s. 113-129.

Jeziński M., Muzyka popularna i jej odbiorcy w poszukiwaniu autorytetu, Wydawnictwo Naukowe Uniwersytetu Mikołaja Kopernika, Torun 2017.

Jeziński M., Muzyka popularna jako wehikut ideologiczny, Wydawnictwo Naukowe Uniwersytetu Mikołaja Kopernika, Torun 2011.

Macdonald D., Teoria kultury masowej, przeł. C. Miłosz, [w:] Antropologia kultury. Zagadnienia $i$ wybór tekstów, red. A. Mencwel, Warszawa 2000, s. 543-554.

Rychlewski M., Rewolucja rocka. Semiotyczne wymiary elektrycznej ekstazy, Oficynka, Gdańsk 2011.

Strawiński I., O wykonaniu, [w:] idem, Poetyka muzyczna, przeł. S. Jarociński, Polskie Wydawnictwa Muzyczne, Kraków 1980, s. 67-78.

\section{Popular music - heard and read}

Summary

The article contains the abstract of individual chapters and presents the most important theses of the author, and disputes the validity of the assertions made. The advantage of the book is in its rich bibliography, numerous examples of music and, most of all, the connection of two perspectives, namely cultural and musicological studies. Inconclusive, however, is the strong opposition that the author presents between popular and classical music. 